Article

\title{
Anti-Candidal Activity and In Vitro Cytotoxicity Assessment of Graphene Nanoplatelets Decorated with Zinc Oxide Nanorods
}

\author{
Graziella Ficociello ${ }^{1}$, Maria Giovanna De Caris ${ }^{2}$, Giusy Trillò ${ }^{1}$, Domenico Cavallini ${ }^{3,4,5}$, \\ Maria Sabrina Sarto ${ }^{3,4,5} \mathbb{C}$, Daniela Uccelletti ${ }^{1,5, * \mathbb{C}}$ and Patrizia Mancini ${ }^{2}$ \\ 1 Department of Biology and Biotechnology, Sapienza University of Rome, Piazzale Aldo Moro 5, \\ 00185 Rome, Italy; graziella.ficociello@uniroma1.it (G.F.); gtgiusy.92@hotmail.it (G.T.) \\ 2 Department of Experimental Medicine, Sapienza University of Rome, Viale Regina Elena 324, \\ 00161 Rome, Italy; mariagiovanna.decaris@uniroma1.it (M.G.D.C); patrizia.mancini@uniroma1.it (P.M.) \\ 3 Department of Aerospace, Electrical and Energy Engineering, Sapienza University of Rome, \\ Via Eudossiana 18, 00184 Rome, Italy; domenico.cavallini@uniroma1.it (D.C.); \\ mariasabrina.sarto@uniroma1.it (M.S.S.) \\ 4 Research Center for Nanotechnology Applied to Engineering of Sapienza University (CNIS), Sapienza \\ University of Rome, Piazzale Aldo Moro 5, 00185 Rome, Italy \\ 5 Sapienza Nanotechnology \& Nano-science Laboratory (SNN Lab), Sapienza University of Rome, \\ Piazzale Aldo Moro 5, 00185 Rome, Italy \\ * Correspondence: daniela.uccelletti@uniroma1.it; Tel.: +39-06-4991-2258; Fax: +39-06-4991-2351
}

Received: 13 August 2018; Accepted: 19 September 2018; Published: 21 September 2018

\begin{abstract}
Candida albicans is the most common pathogenic fungus that is isolated in nosocomial infections in medically and immune-compromised patients. The ability of $C$. albicans to convert its form from yeast to hyphal morphology contributes to biofilm development that effectively shelters Candida against the action of antifungals molecules. In the last years, nanocomposites are the most promising solutions against drug-resistant microorganisms. The aim of this study was to investigate the antifungal activity of graphene nanoplateles decorated with zinc oxide nanorods (ZNGs) against the human pathogen Candida albicans. We observed that ZNGs were able to induce a significant mortality in fungal cells, as well as to affect the main virulence factors of this fungus or rather the hyphal development and biofilm formation. Reactive Oxygen Species (ROS) formation in yeast cells resulted one of the mechanisms of ZNGs to induce mortality. Finally, the toxicity of this nanomaterial was tested also on human keratinocyte cell line HaCaT. Our data indicated that ZNGs resulted not toxic when their aggregation state decreased by adding glycerol as emulsifier to ZNGs suspensions or when $\mathrm{HaCaT}$ cells were grown on ZNGs-coated glasses. Overall, the results that were obtained indicated that ZNGs could be exploited as an antifungal nanomaterial with a high degree of biocompatibility on human cells.
\end{abstract}

Keywords: Candida albicans; biofilm; zinc oxide; nanorods; graphene; $\mathrm{HaCaT}$ cells

\section{Introduction}

The worldwide incidence of infectious diseases continues to increase, and causative microorganisms are increasingly showing (multi-)drug resistance.

Microorganisms such as Escherichia coli, Staphylococcus aureus, and Candida albicans are part of the human microbiota. However, pathogenic forms of these microbes have been implicated in blood or urinary tract infections, gastroenteritis, endocarditis, soft tissue infections, and organ malfunction [1].

The common pathogenic fungus, $C$. albicans is a commensal organism in the mucocutaneous cavities of the skin, vagina, and intestine of humans. However, when the host immune defense 
system become weakened it can cause infections. This fungus represents the fourth-greatest cause of bloodstream infections and together with other opportunistic pathogens that are commonly colonized the human oral mucosa [2]. C. albicans is the most widespread yeast pathogen and is responsible for $50 \%$ of candidiasis, with a mortality rates in nosocomial infection reaching half of infected patients [3]. The pathogenicity of Candida species depends on a variety of determinants such as adhesion factors, germ tube and hyphal and biofilm formation [4]. The germ tube formation represents the transition from a budding state to hyphal cells and it is known to facilitate yeast adherence to epithelial cells and promote the aggregation of yeast cells [5].

Most of antifungal drugs used to treat C. albicans infections target the synthesis and function of ergosterol, which is a major component of the fungal cell membrane. The efficacy of these drugs is compromised by the emergence of resistant strains and the ability of this fungus to form biofilm [6]. Therefore, it is urgent to develop novel non-toxic and efficient agents and strategies against this opportunistic pathogen. Due to the outbreak of the infectious diseases that are caused by different pathogenic microorganism, during the last years, a great importance was given to the research of novel compounds with antimicrobial activity. In this regard, nanomaterials and nanoscience seem to be a good solution in solving this public health problem. Nanotechnologies are widely used in a number of processes, like material science, agricultural production, food industry, cosmetic, as well as sophisticated medicinal techniques (reviewed in [7,8]). Furthermore, nanomaterials have attracted tremendous interest in the fields of photocatalysis, sensors, solar cells, and supercapacitors $[9,10]$. Nanotechnology deals with the manufacture and application of materials with size of up to $100 \mathrm{~nm}$. Inorganic nanoparticles exhibit significantly novel and distinct physical, chemical, and biological properties, whose have elicited much interest over the past few decades because of their potential for biological and pharmaceutical applications [11-13]. In this scenario, the use of inorganic nanoscale materials has been increased also as novel antimicrobial agents, owing to their high surface area relative to volume ratio and the unique physical and chemical properties [14]. In addition, these materials are also more stable at high temperature and pressure [15]. Among these nanomaterials, it has been reported that metallic nanoparticles and metal oxide nanoparticles, such as aluminum oxide $\left(\mathrm{Al}_{2} \mathrm{O}_{3}\right)$, silicon dioxide $\left(\mathrm{SiO}_{2}\right)$, titanium dioxide $\left(\mathrm{TiO}_{2}\right)$, and zinc oxide $(\mathrm{ZnO})$, display the most antibacterial properties [15]. Particularly, zinc oxide shows toxic activity over a wide spectrum of bacterial species [16-18]. ZnO is biocompatible, non-toxic, photochemically stable, as well as it has also been indicated as a generally recognized as safe (GRAS) material by the U.S. Food and Drug Administration (21CFR182.8991) [19]. It shows bactericidal properties over a broad range of Gram-positive as well as Gram-negative bacteria, like Escherichia coli, Streptococcus pyogenes, Bacillus subtilis, Staphylococcus aureus, Salmonella enteritidis, Listeria monocytogenes, Klebsiella pneumonia, Pseudomonas aeruginosa, Salmonella typhimurium, Enterococcus faecalis, etc. (reviewed in [20]). Nano-sized $\mathrm{ZnO}$ exhibits varying morphologies, depending on the process of synthesis. For example, they may be nanorods, nanoplates [21,22], nanowires, nanotubes [23,24], nanospheres [25], nanorings [26], and nanoboxes [27]. ZnO nanoparticles exhibited also significant antifungal properties against important plant pathogenic fungi, such as Botrytis cinerea and Penicillium expansum [28]. Moreover, ZnO nanorod arrays are able to diminish the growth of human opportunistic fungus Candida albicans with stable action for two months [29].

Although there are several advantages of using nanomaterials, the widespread application of these materials confer enormous potential for human exposure and environmental release [30], thus, a better understanding of the toxicological aspects on nanomaterials is essential [31].

The general properties of nanomaterials regarding risk assessment are dependent on the essential characteristics of the nanostructures that are directly related to their synthesis methods [32].

Several nanomaterials with different physical-chemical properties resulted in being permeable to skin. The skin in fact, could serve as an important door for the entry of nanoparticles in the human body [33]. Cytotoxicity can be evaluated in the human adult low calcium high temperature (HaCaT) cell line, since this is derived from adult human skin that exhibits normal differentiation 
capacity $[34,35]$. HaCaT cells are also regarded as a promising alternative approach that is designed to mimic in vivo models in humans as closely as possible [36,37]. Recently, low toxicity of zinc oxide nanorods and microrods has been reported against two different human cell lines: the breast cancer cells MCF7 and the immortalized keratinocytes HaCaT [38]. Moreover, ZnO-NPs are reported as non-toxic to human cells in several studies allowing for their use as antibacterial agents [39,40].

This study investigated the anti-Candida properties of a hybrid nanomaterial made up of graphene nanoplatelets decorated with $\mathrm{ZnO}$ nanorods (ZNGs). We analysed its toxic effect on fungal vitality as well as on C. albicans virulence factors like the hyphal development and biofilm formation. Furthermore, the biocompatibility of ZNGs was assessed while utilizing in vitro tests on HaCaT cells.

\section{Results and Discussion}

\subsection{ZNGs Exert Antifungal Activity in C. albicans Cells}

Previously, it was demonstrated that zinc oxide nanorods decorated graphene nanoplatelets exert a higher antimicrobial activity against both the gram-negative Pseudomonas aeuruginosa and the gram-positive Staphylococcus aureus bacteria, responsible for nosocomial infections as well as for cultural heritage deterioration [41]. Moreover, ZnO-NRs decorated GNPs severely affect the cell vitality of cariogenic bacterium Streptococcus mutans [42].

Thus, we decided to investigate whether this hybrid nanomaterial could also have an anti-fungal effect against the opportunistic pathogen $C$. albicans.

We first analysed the ZNGs ability to induce C. albicans cell death. For this purpose, we employed the non-cell permeable DNA dye SYTOX Green. Indeed, this fluorescent dye is able to penetrate only the dying cells. Yeast cells were exposed for $6 \mathrm{~h}$ and $12 \mathrm{~h}$ to increasing concentrations of ZNGs and is then stained with SYTOX Green. A shown in Figure 1A,B, although ZNGs were not effective at the lowest concentration of $10 \mu \mathrm{g} / \mathrm{mL}$, a noteworthy fungal mortality was highlighted when ZNGs concentration was increased up to $250 \mu \mathrm{g} / \mathrm{mL}$ (Figure 1A). The SYTOX Green positive cells rose to $\sim 20 \%$ both after $6 \mathrm{~h}$ and $12 \mathrm{~h}$ of ZNGs treatment at $50 \mu \mathrm{g} / \mathrm{mL}$ (Figure 1B).

A)
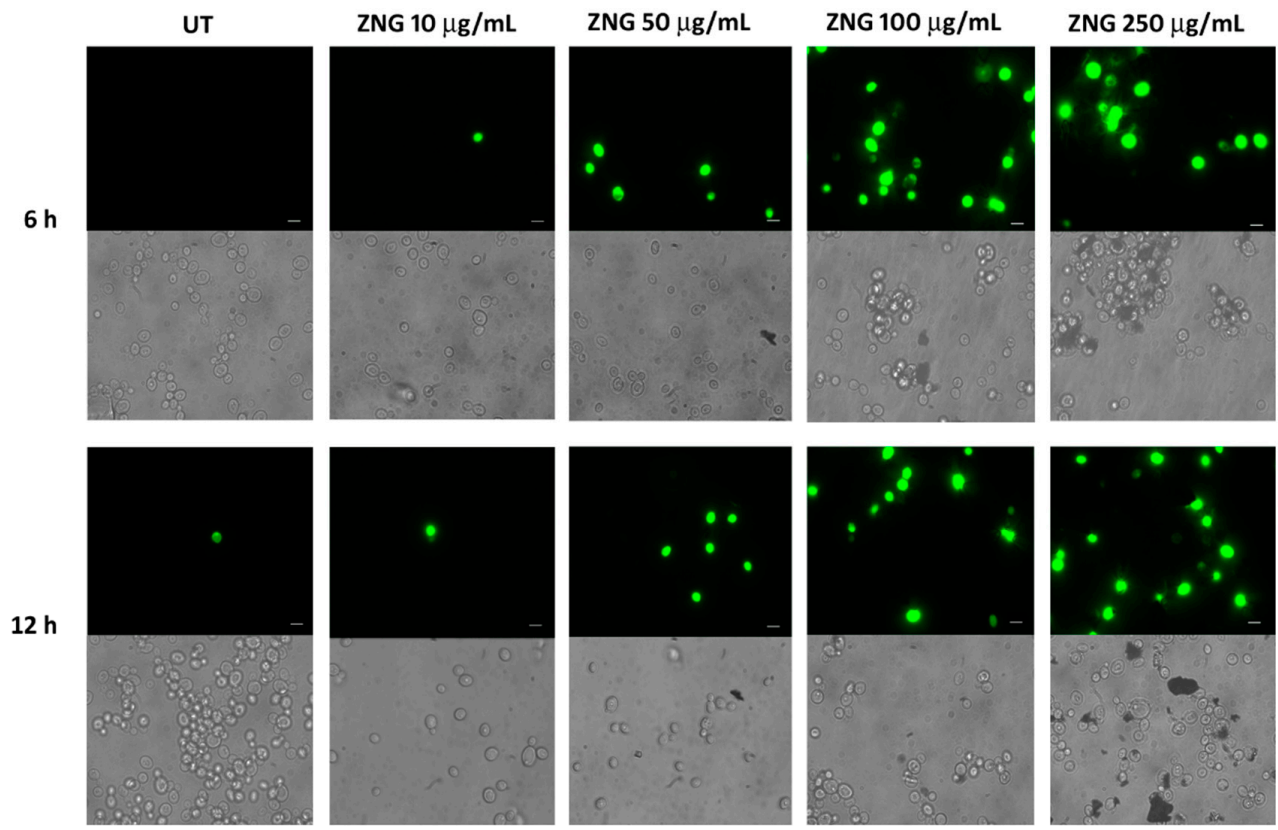

Figure 1. Cont. 


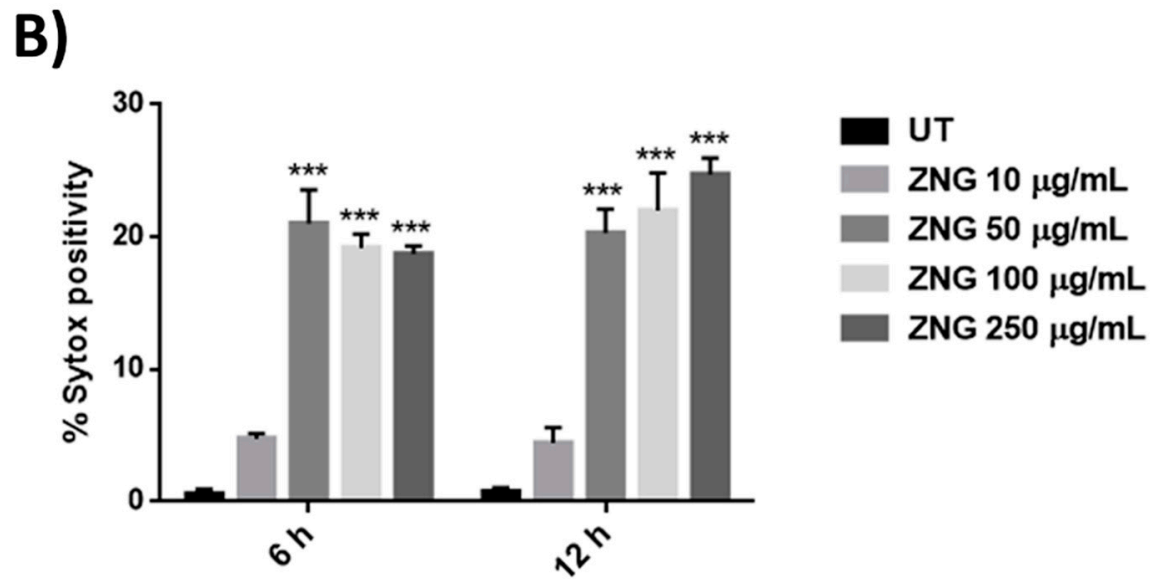

Figure 1. Viability of $C$. albicans treated with $\mathrm{ZnO}$ nanorods (ZNGs) material. (A) SYTOX Green staining of C. albicans cells exposed or not to ZNGs for $6 \mathrm{~h}$ or $12 \mathrm{~h}$. Scale bar $5 \mu \mathrm{m}$; (B) Percentage of fluorescent died cells relative to the total cells. The data were analyzed by two-way analysis of variance (ANOVA), followed by Bonferroni's test. $\left({ }^{* *} p<0.001\right)$.

To confirm this data, C. albicans cells were incubated for $24 \mathrm{~h}$ with different concentrations of ZNGs and then the Colony Forming Units (CFU) assay was performed. After a long-term exposure, also $10 \mu \mathrm{g} / \mathrm{mL}$ ZNGs induced a slight mortality of C. albicans, as long as the cell survival was decreased by $50 \%$ when fungal cells were exposed to $50 \mu \mathrm{g} / \mathrm{mL}$ ZNGs. However, the lowest cell viability was achieved at the two higher concentrations with a mortality rate of about $80 \%$ (Figure 2).

Based on these results ZNGs displayed a significantly antifungal effect against the opportunistic fungus $C$. albicans. In addition, zinc oxide nanoparticles were shown to induce a reduction of growth rate, as well as the cell viability of $C$. albicans, with a dose-effect response that was very similar to ZNGs [43].

It was reported that $\mathrm{ZnO}$ nanorods that are vertically aligned on a glass surface exert an inhibitory action on C. albicans growth [29]. This is probably due, as in the case of ZNGs, to the increased surface of the nanomaterial that enhanced the contact between $\mathrm{ZnO}$ nanorods and the cells.

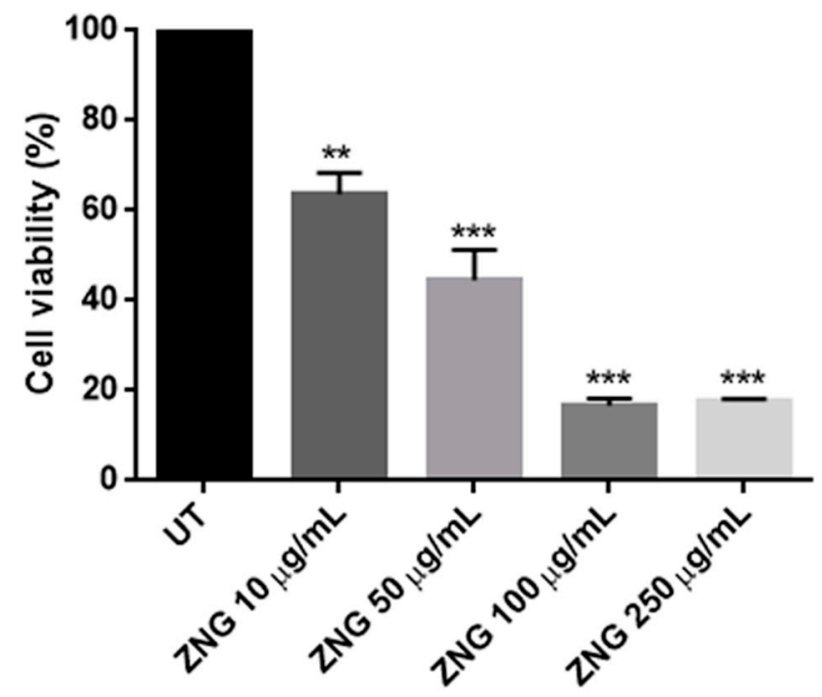

Figure 2. Analysis of Colony Forming Units (CFU) counting for Candida albicans cells untreated (UT) or treated with ZNG nanomaterials at different concentrations. Statistically significant differences with the untreated group were calculated by using one-way ANOVA with Bonferroni's post-test. $(* * p<0.01$, *** $p<0.001)$. 


\subsection{ZNGs Induce Intracellular ROS Accumulation}

Oxidative stress mediated by ROS is a well-known inducer of cytotoxicity and cell death in C. albicans [44]. Therefore, we examined the possible role of ROS in anti-candidal activity of ZNGs. To this aim, we used the cell permeable dye $\mathrm{H}_{2}$ DCFDA that, when binding the intracellular ROS, is rapidly oxidized into the highly fluorescent DCF [45]. C. albicans cells were exposed with the increasing ZNGs concentrations for $6 \mathrm{~h}$ and $12 \mathrm{~h}$. As shown in Figure 3, the hybrid material at the concentrations of 100 and $250 \mu \mathrm{g} / \mathrm{mL}$ induced ROS accumulation in both a time- and dose-dependent manner, meanwhile the two lowest concentrations were able to induce ROS accumulation only after $12 \mathrm{~h}$ of exposure.



Figure 3. Detection of ROS content using $\mathrm{H}_{2}$ DCFDA staining. C. albicans cells untreated (UT) or treated with the various concentrations of ZNGs, for $6 \mathrm{~h}$ and $12 \mathrm{~h}$, were stained to detect the intracellular ROS formation. The bars represent the percentage of fluorescence-positive cells with respect to total cells. Means and SDs are shown $\left({ }^{*} p<0.05,{ }^{* *} p<0.01\right.$, and ${ }^{* *} p<0.001$ when compared with the untreated cells).

In the light of these results, we supposed that the antifungal effect of ZNGs against $C$. albicans was due to the increased ROS levels. It has been reported that free radicals that are produced by $\mathrm{ZnO}$ nanoparticles in water suspensions are directly correlated with an increase of ROS productions, as well as a reduction of cell viability in C. albicans cells [43].

However, for zinc oxide-based nanomaterials, two mechanisms have been proposed for their antimicrobial action. The first is that $\mathrm{ZnO}$ in aqueous solution generates hydrogen peroxide $\left(\mathrm{H}_{2} \mathrm{O}_{2}\right)$ from its surface, that can penetrate the cell membrane of microorganisms and kill them, inducing oxidative stress. The second one is the release of zinc ions in medium with effects on active transport as well as on the amino acid metabolism [46]. Since we previously showed that the release of zinc ions by ZNGs in the medium is very low [42] we investigated if the main mechanism of toxicity against C. albicans was due to the production of $\mathrm{H}_{2} \mathrm{O}_{2}$, that causes the oxidative stress in fungal cells. To assess this hypothesis, we performed the cell vitality assay in the presence of $10 \mathrm{mM}$ histidine, which is a quencher of hydroxyl radicals and singlet oxygen [43]. The effect of histidine on ZNGs toxicity was tested by adding this scavenger to fungal cultures containing different concentrations of nanomaterials. We found that histidine was able to recover the $C$. albicans viability only partially, with the cell survival percentage raised from $47 \%$ to $62 \%$ in the case of cells that were treated with $50 \mu \mathrm{g} / \mathrm{mL} Z \mathrm{ZNGs}$, while a cell survival from $15 \%$ to $55 \%$ was observed when the two highest concentrations of ZNGs were utilized (data not shown). These results indicate that the toxicity exerted by ZNGs on C. albicans cells is probably partly due to the intracellular ROS accumulation and partly to mechanical damages that are caused by $\mathrm{ZnO}-\mathrm{NRs}$ that act as nano-needles. 


\subsection{Hyphal Development Is Affected by ZNGs Treatment}

The transition from yeast to hyphal form is essential for the pathogenicity of this opportunistic fungus [47]. Indeed, while the yeast morphology plays a key role in the dissemination and systemic infection, the hyphal development is decisive for the biofilm formation and it is important to establish and maintain the infection [48]. Moreover, the germ tubes also give resistance against the phagocytosis from immune system cells when compared with the budding form [49].

For this reason, we next examined the effect of ZNGs on C. albicans hyphal elongation on solid medium by cultivating fungal cells and observing colony morphology on Spider agar supplemented with the various concentrations of ZNGs at $37^{\circ} \mathrm{C}$ (Figure $4 \mathrm{~A}$ ). This hybrid nanomaterial exerted a slight effect at the concentration of $100 \mu \mathrm{g} / \mathrm{mL}$, however, it found a strong reduction of filamentation when C. albicans was treated with the highest concentration of ZNGs (Figure 4A). We also examined the impact of ZNGs on hyphal growth in liquid Spider media. In this case, C. albicans cells that were treated with $100 \mu \mathrm{g} / \mathrm{mL}$ or $250 \mu \mathrm{g} / \mathrm{mL}$ ZNGs showed a considerable arrest of the hyphal development (Figure 4B), with a decrease of long hyphae of $96 \%$ and $99 \%$, respectively, when compared to the untreated sample (Figure 4C). Conversely, the exposure to the lowest concentrations of the hybrid nanomaterials was not able to alter the hyphal morphology, both on Spider agar and in liquid medium (data not shown).
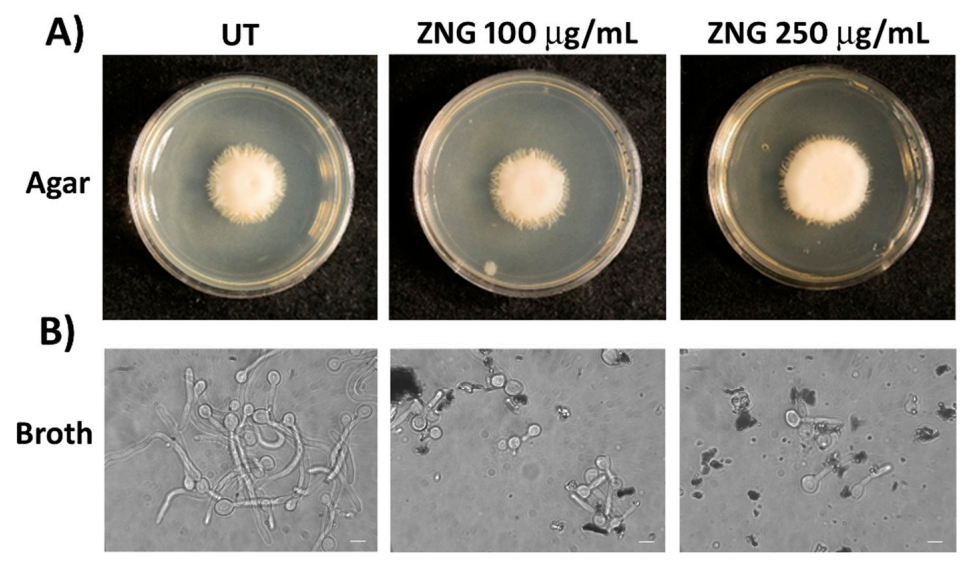

C)

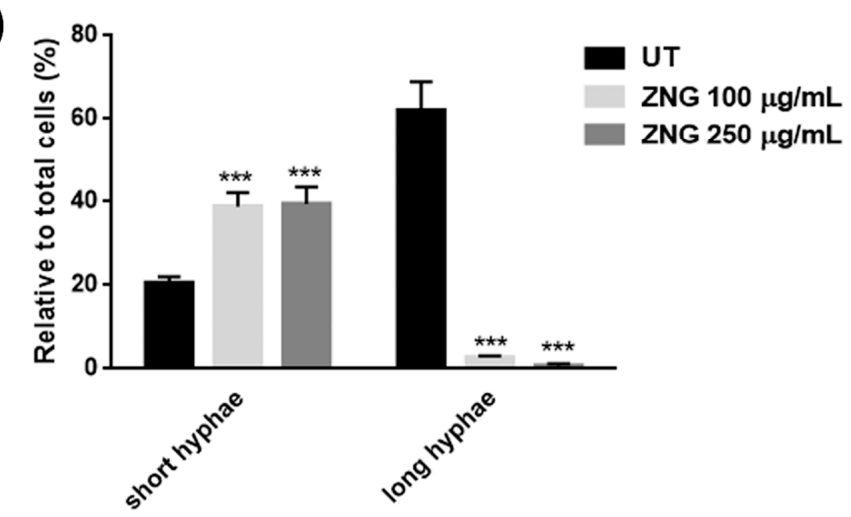

Figure 4. Inhibition of hyphal formation by ZNGs. (A) Effect of $100 \mu \mathrm{g} / \mathrm{mL}$ and $250 \mu \mathrm{g} / \mathrm{mL}$ ZNGs on C. albicans hyphal elongation on solid Spider medium. Plates were incubated at $37^{\circ} \mathrm{C}$ for five days; (B) ZNGs activity on C. albicans hyphal formation in liquid Spider medium for $2.5 \mathrm{~h}$ at $37^{\circ} \mathrm{C}$. Scale bar $5 \mu \mathrm{m}$; and, (C) Percentage of short and long hyphae observed after $2.5 \mathrm{~h}$ of treatment with ZNGs. Untreated cells (UT) were used as control. A two-way ANOVA analysis with the Bonferroni post-test was used to assess the statistical significance ${ }^{* * *} p<0.001$ with respect to untreated cells). 
Similarly to our findings, it was showed that silver nanoparticle decorated with hydroxyapatite are able to reduce the hyphal cell density of C. albicans cells, although they were exposed to high concentrations of this nanomaterial [50]. Moreover, biogenic silver nanoparticles synthetized while using the aqueous leaf extract of Polyalthia longifolia significantly reduce the serum-induced hyphal form morphogenesis in C. albicans [51]. Recently, it was reported that nanoparticles induce the formation of pseudo-hyphae, an index of yeast cellular stress [52]. Currently, few works describe the effects of graphene- or zinc oxide-based nanomaterials on hyphal formation of C. albicans. It is reported that ZnO-NPs synthetized from leaf extract of Crinum latifolium are able to inhibit the hyphal development. This nanomaterial induces a reduction of germ tube formation of $34 \%$ when it is used at the concentration of $250 \mu \mathrm{g} / \mathrm{mL}$ [53]. We previously found that ZNGs induce mechanical injuries against the bacteria $S$. aureus and P. aeruginosa. The ZnO-NRs protrude from the GNPs acting as nanoneedles that pierce the cell wall. Moreover, the GNPs platelets could offer a large surface that hampers the hyphal development.

\subsection{ZNGs Strongly Reduce Cell Viability in C. Albicans Biofilm}

The ability of Candida spp. to form biofilms on medical devices, such as catheters, contact lenses, dentures, and voice prostheses represents another healthcare problem that is associated with this pathogenic fungus [54,55]. The capability of C. albicans to form biofilm is the major factor that contributes to its high resistance to antifungal drugs [56,57] and Candida biofilm associated with medical devices tend to be more problematic to eradicate than bacterial infections [58]. Indeed, C. albicans resistance is reported for all of the antifungal drugs that have been widely deployed in therapy [59].

Thus, there is an urgent need for novel strategies for the prevention and treatment of C. albicans biofilm development.

In this work, we assessed the toxicological capability of ZNGs on C. albicans biofilm, while using a model of biofilm formation on the 12-wells microtiter plates. Fungal cells were grown for $24 \mathrm{~h}$ or $48 \mathrm{~h}$, in the presence of the increasing concentrations of ZNGs in the appropriate conditions to induce biofilm formation. We observed that ZNGs were not able to prevent the biofilm development in the treated wells when compared to the control. Furthermore, optic microscope observations revealed that the cell adhesion was not altered by ZNGs exposure. Afterwards, we stained mature biofilms with the SYTOX Green dye to detect the cell mortality. After $24 \mathrm{~h}$ of exposure in the presence of ZNGs, no differences in the cell vitality were observed between the control and treated samples. On the contrary, ZNGs exhibited a notable fungicidal effect on C. albicans biofilm after $48 \mathrm{~h}$ of treatment, already at the low concentration of $10 \mu \mathrm{g} / \mathrm{mL}$ (Figure 5).

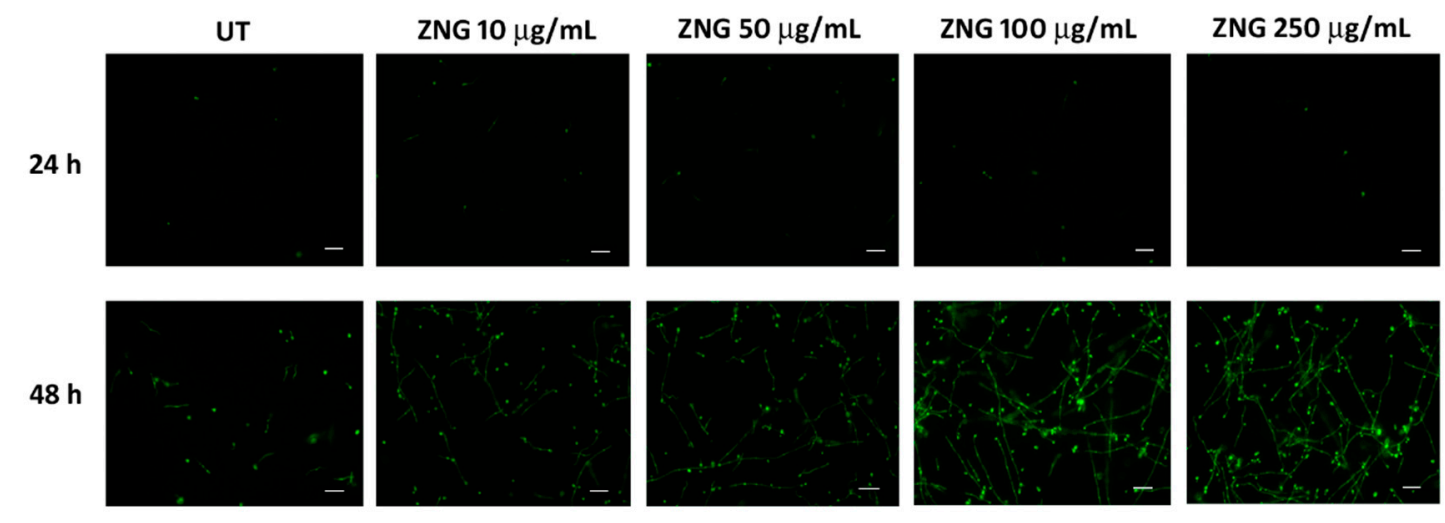

Figure 5. Fungicidal activity of ZNGs nanomaterials on C. albicans biofilm. The biofilm formation, at the indicated concentrations of ZNGs, was obtained in 12 -well cell culture plates at $37^{\circ} \mathrm{C}$ for $24 \mathrm{~h}$ or $48 \mathrm{~h}$. Afterward, the cells were stained with SYTOX Green and visualized at $32 \times$ magnification. Untreated biofilm (UT) was used as negative control. Scale bar $20 \mu \mathrm{m}$. 
As mentioned before, the ability to form biofilm is the main virulence factor of C. albicans. Thus, investigate the toxicity against the biofilm is important to develop novel nanomaterials with anticandidal activity. In literature, the inhibition of $C$. albicans biofilm by other nanoparticles has been reported, golden nanoparticles (AuNPs) significantly reduce the biofilm density of $C$ albicans cells, although they resulted ineffective on yeast growth and hyphal development [60]. Biogenic selenium nanoparticles, as produced by reactions of reduction of environmental bacterial isolates, inhibit biofilm formation of $60-70 \%$, without affecting the growth rate of this pathogenic fungus [61]. Zinc oxide nanomaterials coated or not with different molecules were tested for their ability to prevent the biofilm formation of $C$. albicans. For example, zinc oxide nanoparticles that were coated with biopolymer gelatin or chitosan-linoleic acid led to a weak adherence of biofilm formation [62,63]. Moreover, it was found that $\mathrm{ZnO}-\mathrm{NPs}$ had a toxic effect on C. albicans biofilm inducing alterations in the extracellular matrix [53]. The effects on biofilm extracellular matrix were reported also for ZNGs that inhibit the exopolysaccharide (EPS) production of cariogenic bacterium S. mutans [42].

\subsection{Biocompatibility of HaCaT Cells}

Since we have previously demonstrated that the human cell lines HaCaT and MCF7 show a very low cytotoxicity when exposed to ZnO-NRs and ZnO-MRs [38], in this report, we wondered whether $\mathrm{HaCaT}$ cells had a low cytotoxicity also towards ZNGs. For this purpose, human keratinocytes were incubated with different concentrations of ZNGs suspended in culture medium (DMEM) for $24 \mathrm{~h}$. Results obtained show that already at $10 \mu \mathrm{g} / \mathrm{mL}$ of ZNGs concentration a reduction of cell viability was noticeable, which became more evident at higher concentrations, indicating a dose-dependent cytotoxic effect of ZNGs (Figure 6A). We assume that this result may depend on the strong aggregation of ZNGs suspended in the culture medium observed at higher concentrations. As the cytotoxicity of a nanomaterial depends on its shape, size and aggregation state, it becomes essential to increase its biocompatibility and stability in different aqueous solutions or different synthesis preparation. For example, Harper and colleagues found that the toxicity of golden nanoparticles coated with Glutathione (Au-GSH NPs) was significantly reduced and the ligand structure was ameliorated when the ultracentrifugation purifications were implemented during the multi-step synthesis and surface modification of Au-GSH nanoparticles [64].

Moreover, biocompatibility can be enhanced by adding to the suspension of nanomaterials reagents, such as chitosan [65], bovine $\alpha$-lactalbumin [66], or polyethylene glycol [67].

In this report, in order to reduce the cytotoxicity of ZNGs, we employed glycerol, a stabilizer of emulsions [68], which is generally used to increase the biocompatibility of different types of nanoparticles [69]. The incubation of HaCaT cells with ZNGs suspended in culture medium with the addition of $4 \%$ glycerol, led to a marked improvement in cell viability (Figure 6B). These results can be explained by the fact that glycerol could behave like an osmoprotector. Indeed, Corrales et al. reported that glycerol has an osmoprotective function in human corneal epithelial cells. They demonstrate that the addition of glycerol to medium of isotonic, physiologic osmolarity is responsible for the strong reduction of activation of Mitogen-activated protein kinases (MAPKs), which represents a marker of the osmolarity cell response [70].

For this reason, in the following experiments we used ZNGs dispersed in culture medium with $4 \%$ of glycerol. 
A)



B)

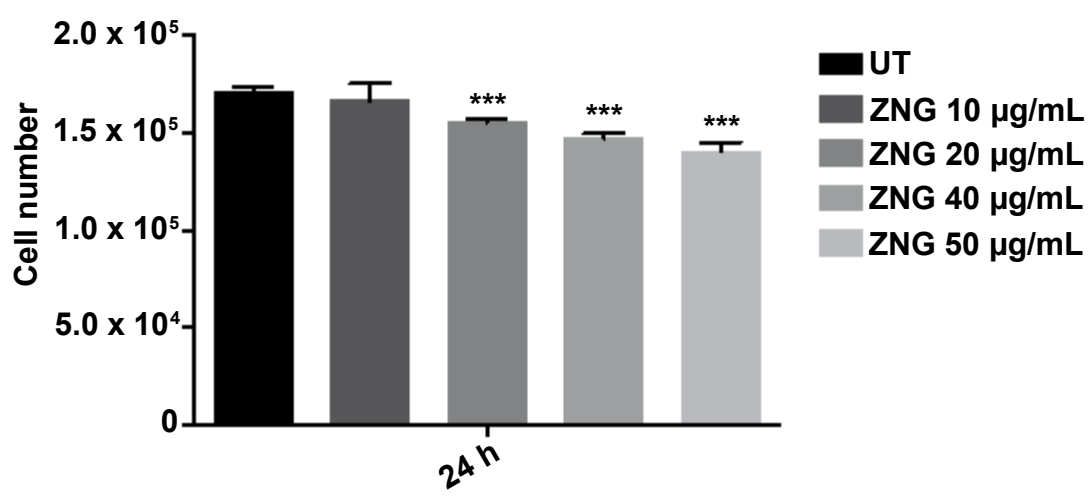

Figure 6. Cell viability of HaCaT cells after treatment with ZNGs suspended in (A) Dulbecco's Modified Eagle's Medium (DMEM) or (B) 4\% glycerol in DMEM. The cell count was performed by the Trypan Blue dye exclusion test, and the values were reported as total number of living cells. Data are expressed as mean $\pm \mathrm{SD}, n=3$. Statistical analysis was performed by one-way analysis of variance (ANOVA) method coupled with the Bonferroni post-test ${ }^{* * *} p<0.001$ compared to the untreated sample (UT)).

\subsection{Cell Proliferation and Cytoskeleton Morphology in $\mathrm{HaCaT}$ Cells}

Since microtubules are highly dynamic components of the cytoskeleton, being essential for intracellular transport, organization of organelles and cell division [71], here we have analyzed cell proliferation and the distribution and morphology of tubulin, which is a fundamental component of microtubules.

For cell proliferation, HaCaT cells were incubated or not with ZNGs for 24,48 and $72 \mathrm{~h}$. The results obtained show a normal proliferative trend (Figure 7A). In particular, the growth curves of the cells treated with $10 \mu \mathrm{g} / \mathrm{mL}$ or $50 \mu \mathrm{g} / \mathrm{mL}$ of ZNGs exhibited an exponential trend, similar to that of the control cells, although a very lower proliferation rate was present already at 24 hours in a dose-dependent manner (Figure 7A). These results indicate that the ZNGs do not impair the proliferation of HaCaT cells. For tubulin analysis, we performed an immunofluorescence study on $\mathrm{HaCaT}$ cells that were treated with ZNGs, as above. Fluorescence images show a normal localization and organization of the tubulin, in all the samples examined (Figure 7B). Moreover, well organized mitotic spindles are very evident, indicating that the ZNGs did not alter the normal distribution and morphology of microtubules, and that cells are in active proliferation rate (Figure 7B).

We also examined the actin cytoskeleton organization in cells that were treated with ZNGs. Immunofluorescence images show that actin was mainly arranged in filopodia (Figure S1), probably 
used by the cells as probes of the surrounding environment [72]. After treatment with $10 \mu \mathrm{g} / \mathrm{mL}$ or $50 \mu \mathrm{g} / \mathrm{mL}$ of ZNGs, filopodia appeared to be more numerous and arranged in an orderly manner along the cell membrane with respect to the control cells (Figure S1), in agreement with our previously report where zinc oxide-based nanomaterials induce the reorganization of actin cytoskeleton mainly in filopodia [38]. Filopodia are highly dynamic structures that the cells can use as sensors, to evaluate the surrounding environment stimulating a response through the activation of specific signaling pathways [72].

A)

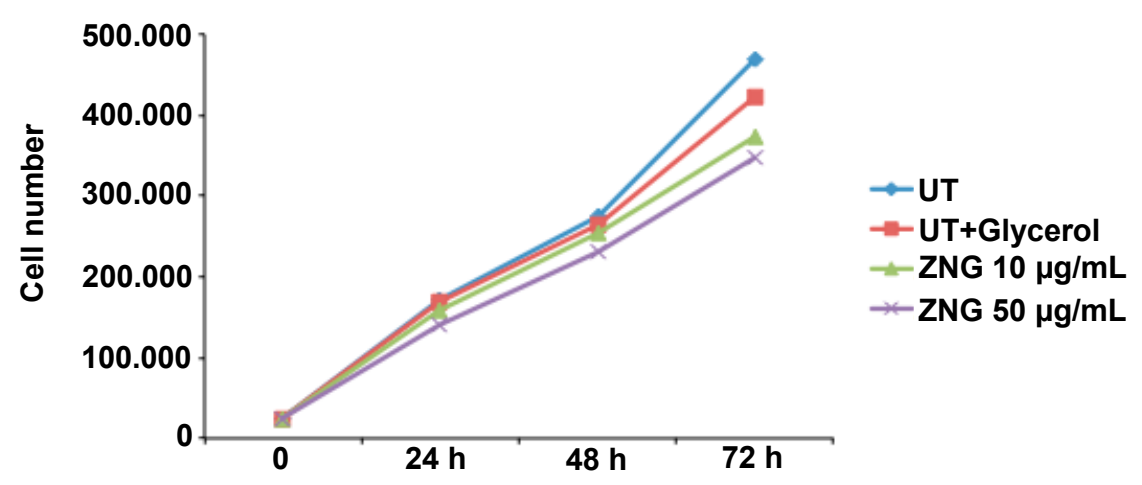

B)
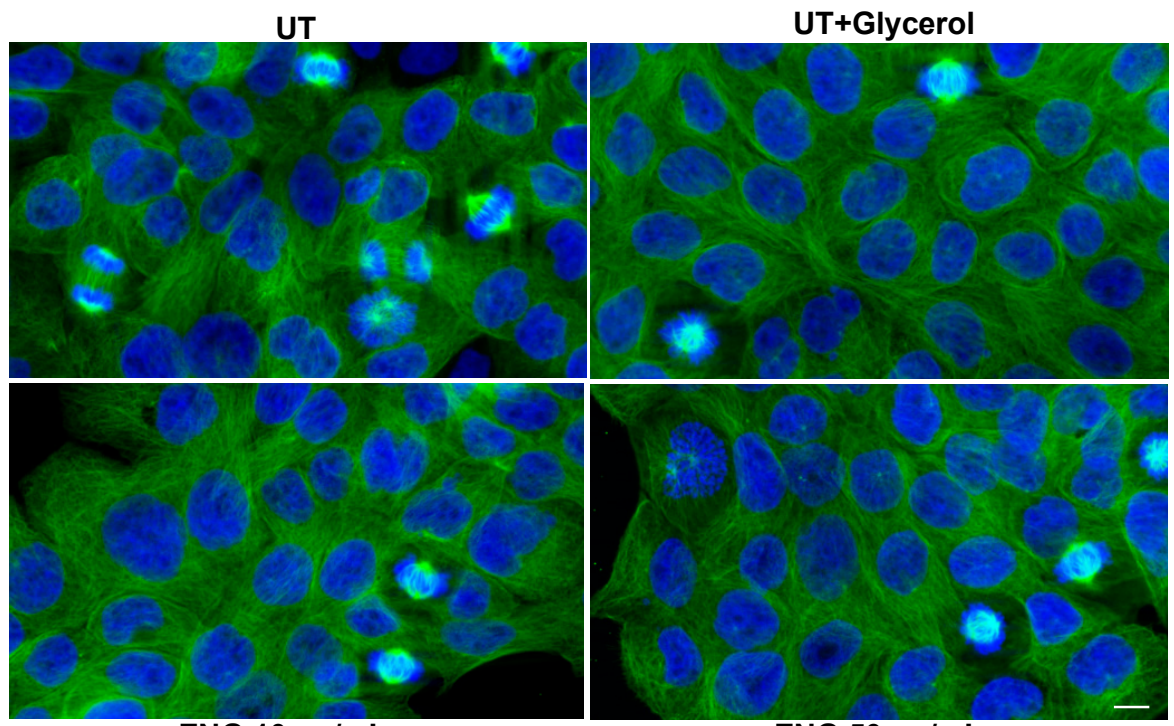

ZNG $10 \mu \mathrm{g} / \mathrm{mL}$

ZNG $50 \mu \mathrm{g} / \mathrm{mL}$

Figure 7. (A) Cell proliferation and (B) immunofluorescence analysis of FITC-tubulin staining of HaCaT cells after exposure to ZNGs. Scale bar represents $20 \mu \mathrm{m}$.

\subsection{Intracellular ROS Detection in HaCaT Cells}

ROS generation was next evaluated while using the dye H2DCFDA. HaCaT cells exposed or not to ZNGs at concentrations of 10 or $50 \mu \mathrm{g} / \mathrm{mL}$ for $24 \mathrm{~h}$, showed a very slight non-significant increase in the number of ROS positive cells with respect to the control cells (Figure 8). This result, which indicates a very low toxicity of the ZNGs used in this in vitro system, is in agreement with the data reported for the ROS generation in the presence of ZnO-NR and ZnO-MR in HaCaT and MCF7 cells [38]. 


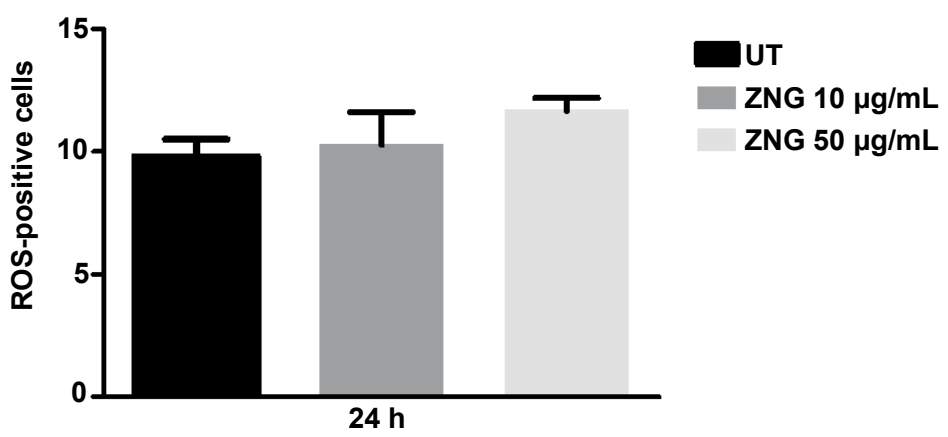

Figure 8. Intracellular ROS production of HaCaT cells after treatment with ZNGs or not (UT) for $24 \mathrm{~h}$. Data are expressed as mean $\pm \mathrm{SD}$. Statistical analysis was performed by one-way analysis of variance (ANOVA) method coupled with the Bonferroni post-test. Values obtained are not significant.

This finding could be explained by the thermal decomposition method used for the preparation of the $\mathrm{ZnO}$ utilized here that provides the release of very few zinc ions [73]. In fact, at high concentrations zinc ions are considered to be mainly responsible of the induction of oxidative stress, and, therefore, of the formation of ROS in the cells [74] whereas, the decrease of $\mathrm{ZnO}$ nanoparticles is responsible for a reduced toxicity, as demonstrated in rodent and zebrafish models [75].

\subsection{MTT on ZNGs Coated Glass Slides}

Many cytotoxic experiments have been carried out in vitro following the traditional approaches created for soluble nanoparticles [76]. In these conditions, nanomaterials tend to aggregate and sediment. To abolish or reduce these problems, many authors grow cells on nanomaterials-coated scaffolds, as recently reported by Lasocka et al. that demonstrated the biocompatibility of L929 cells that were grown on graphene-coated microscope glass slides [77].

Based on this information, here, we have coated glass slides with ZNGs, and, on these, seeded the cells. To detect biocompatibility, we measured the optical density of living cells while using the MTT assay. After $24 \mathrm{~h}$ of growth on ZNGs coated glass slides, human keratinocytes showed a slight improvement in cell viability, also confirmed at $48 \mathrm{~h}$ in comparison with the cells seeded on uncoated glass (Figure 9). This result leads us to hypothesize that ZNGs are uniformly distributed and dispersed on the solid surface, indicating that ZNGs-coated substrates are a good scaffold for the cells, allowing for their use in several applications.

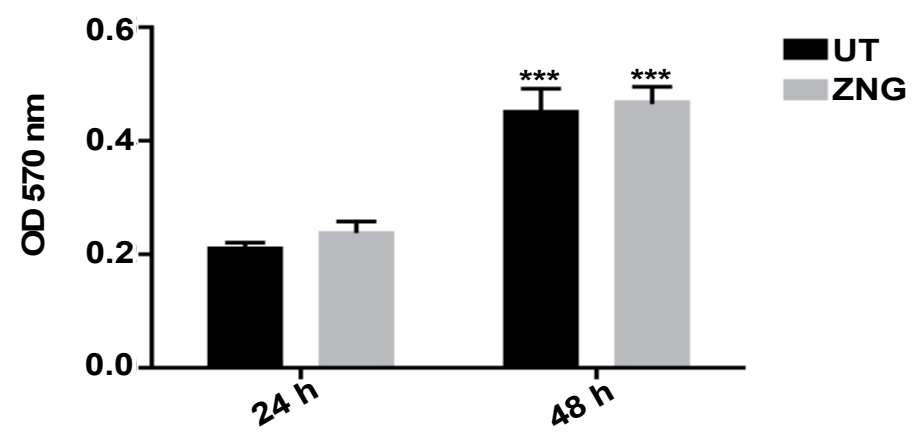

Figure 9. Analysis of cell viability, measured by the thiazolyl blue tetrazolium bromide (MTT) assay, of HaCaT cells grown on ZNGs coated glass for 24 and $48 \mathrm{~h}$. Data are expressed as mean \pm SD. Statistical analysis was performed by one-way analysis of variance (ANOVA) method coupled with the Bonferroni post-test ${ }^{* * *} p<0.001$ compared to the untreated sample (UT)). 
Our result is in agreement with that of Wang et al., which showed that $\mathrm{ZnO} /$ graphene oxide (GO) composites have a very low cytotoxicity on HeLa cells when compared to $\mathrm{ZnO}$ and $\mathrm{ZnO}$ nanoparticles (NPs) alone [78]. Moreover, nanohybrid materials composed by GO and chitosan showed a good biocompatibility regards murine fibroblast MC3T3 and human neuroblastoma SH-SY5Y cell lines [79] and L929 cells [80]. Thus, our findings demonstrate that the ZNG nanomaterials may be used as scaffold of different substrates for application in various fields, such as tissue recovery and engineering.

\section{Materials and Methods}

\subsection{Materials}

Glycerol anhydre, Trypan blue, anti- $\alpha$-tubulin-FITC monoclonal antibody, PhalloidinTetramethylrhodamine B isothiocyanate (Phalloidin-TRITC), 4',6-diamidine-2'-phenylindole dihydrochloride (DAPI), 2' $7^{\prime}$-Dichlorofluorescin diacetate $\left(\mathrm{H}_{2} \mathrm{DCFDA}\right)$, and thiazolyl blue tetrazolium bromide (MTT) were obtained from Sigma-Aldrich (Saint Louis, MO, USA).

\subsection{Production and Morphology of Nanomaterials}

Graphene nanoplatelets decorated with zinc oxide nanorods were produced and characterized as described in Chandraghari et al. [81]. ZNG is a hybrid material consisting of an array of vertically aligned ZnO-NR, directly grown on a graphene nano-platelet (GNP) flake. ZNGs were produced by a simple and cost-effective hydrothermal process, made up of two main steps, namely seed layer deposition and NRs growth. The first step involves the deposition of nucleation sites for the subsequent growth process. Briefly, the seed deposition consists in the preparation of an alcoholic solution of isopropanol and zinc acetate hexahydrates, in which a certain amount of graphene nanoplatelets (GNP) are suspended through magnetic agitation; the resulting suspension is then heated at $300{ }^{\circ} \mathrm{C}$ until thorough evaporation of the solvent. The second step consists in a hydrothermal process. This step is realized by immersing seed-coated GNPs in an equimolar aqueous solution of zinc nitrate dihydrate and hexamethylenetetramine for $4 \mathrm{~h}$ at $60^{\circ} \mathrm{C}$ [81]. ZNGs morphology has been characterized through Field Emission-Scanning Electron Microscopy (FE-SEM) using a Zeiss Auriga (Carl Zeiss, Oberkochen, Germany) platform, operated at $5 \mathrm{kV}$ accelerating voltage (the complete set of micrographs is available at SNN-Lab, Sapienza University of Rome). Prior to imaging, no metallic coating was applied on the samples. FE-SEM micrographs reported in Figure S2A-C show ZNGs surface topography, while Figure S2D shows pristine GNPs, i.e., before the hydrothermal process. The average lateral dimensions of GNPs are in the $0.5 \mu \mathrm{m}$ to $15 \mu \mathrm{m}$ range, with thickness varying between $1 \mathrm{~nm}$ and $20 \mathrm{~nm}$. ZnO-NRs have a diameter of $20-40 \mathrm{~nm}$ and a length of several hundred of nanometers (200-400 nm).

\subsection{Fungal Strain and Culture Conditions}

Candida albicans strain (ATTC 10231) was obtained from the American Type Culture Collection (ATCC) (Manassas, VA, USA). Fungal cells were routinely grown at $30{ }^{\circ} \mathrm{C}$ in YPD medium $[1 \%$ yeast extract, $1 \%$ peptone, and $2 \%$ glucose-DIFCO (Difco, Becton Dickinson, Sparks, MD, USA)] under aerobic conditions. Strict anaerobic conditions were achieved while using OXOID Anaerobic Gas pack AN0010C (Oxoid Ltd., Basingstoke, Hants, UK), according to the manufacturer's instructions.

To induce hyphal formation in vitro, C. albicans cells were grown at $37^{\circ} \mathrm{C}$ in Spider medium [82].

To prepare a standard suspension for biofilm development, fungal cells were inoculated into YNB medium [ $(0.67 \%$ yeast nitrogen base w $/ \mathrm{o}$ amino acids, $2 \%$ dextrose -DIFCO (Difco, Becton Dickinson, Sparks, MD, USA), and incubated for $18 \mathrm{~h}$ at $30^{\circ} \mathrm{C}$ with agitation.

\subsection{Cell Viability Assay of Yeast Cells}

The survival of $C$. albicans following ZNGs treatment was evaluated by Colony Forming Units (CFU) assay. An aliquot of $5 \times 10^{7}$ cells $/ \mathrm{mL}$ from overnight culture was incubated at $30^{\circ} \mathrm{C}$ for $24 \mathrm{~h}$ under gentle shaking with different concentrations of $Z N G s$ suspended in $\mathrm{H}_{2} \mathrm{O}_{\mathrm{dd}}$. The yeast cells were 
serially diluted and then spread on YPD agar plates. Yeast cultures grown under the same conditions without the addition of ZNGs served as controls. The survival rate was calculated according to the equation: $[(\mathrm{CFU} / \mathrm{mL})$ of exposed cells $/(\mathrm{CFU} / \mathrm{mL})$ of untreated sample $] \times 100$.

\subsection{Evaluation of Intracellular ROS Formation in Yeast Cells}

The intracellular ROS production was detected while using the fluorescent probe $\mathrm{H}_{2}$ DCFDA. C. albicans cells, grown overnight in YPD medium at $30^{\circ} \mathrm{C}$, were washed with phosphate buffered saline buffer (PBS), and incubated with different concentrations of ZNGs for $6 \mathrm{~h}$ and $12 \mathrm{~h}$ at $30^{\circ} \mathrm{C}$. After centrifugation, the cells were resuspended in a solution of $10 \mu \mathrm{M} \mathrm{H}_{2}$ DCFDA for $30 \mathrm{~min}$ in the dark and washed twice with PBS. The fluorescent intensity was analysed with a Zeiss AxioVert 25 microscope (Carl Zeiss, Oberkochen, Germany). For each sample, the percentage of fluorescence was assessed in relation to the total cells per image.

\subsection{Biofilm Assay}

C. albicans biofilm formation was performed, as described by Thein et al. [83], with some modifications. Briefly, fungal cells were grown in $0.67 \%$ yeast nitrogen base w/o amino acids (YNB), supplemented with $100 \mathrm{mM}$ glucose for $18 \mathrm{~h}$ at $30^{\circ} \mathrm{C}$. Afterwards, the cells were washed twice with PBS and resuspended to the concentration of $1 \times 10^{7}$ cells $/ \mathrm{mL}$ in PBS. $500 \mu \mathrm{L}$ of the standard cell suspension $\left(1 \times 10^{7}\right.$ cells $\left./ \mathrm{mL}\right)$ were transferred into the wells of pre-sterilized, polystyrene, flat bottom 24-well plates (Falcon; Becton Dickinson, Lincoln Park, NJ, USA). The plates were incubated for $1.5 \mathrm{~h}$ at $37^{\circ} \mathrm{C}$ in a static condition to promote the adhesion phase. After that, non-adherent cells were removed by washing the biofilms once with PBS and $1 \mathrm{~mL}$ of fresh medium (YNB and $100 \mathrm{mM}$ Glucose) supplied with different concentrations of ZNGs (10, 50, 100, and $250 \mu \mathrm{g} / \mathrm{mL}$ ) was added to selected wells. The plates were incubated for $24 \mathrm{~h}$ or $48 \mathrm{~h}$ at $37^{\circ} \mathrm{C}$ in static and anaerobic condition.

\subsection{SYTOX Green Staining}

Vegetative cells of $C$. albicans was exposed for $6 \mathrm{~h}$ or $12 \mathrm{~h}$ to $10,50,100$, and $250 \mu \mathrm{g} / \mathrm{mL}$ ZNGs, at $30{ }^{\circ} \mathrm{C}$ shaking gently. After that, the cells were washed twice with PBS and then stained with $1 \mu$ M SYTOX green (Thermo Fisher Scientific; Waltham, MA, USA) for $15 \mathrm{~min}$ at room temperature. Epifluorescence microscopy was carried out with a Zeiss AxioVert 25 microscope (Carl Zeiss, Oberkochen, Germany) fitted with a $\times 100$ immersion objective and a standard filter set. Percentage of fluorescent cell was calculating relative to the total cells per image.

For biofilm staining, after the incubation for $24 \mathrm{~h}$ or $48 \mathrm{~h}$, the wells were washed once with PBS and then stained with $1 \mu \mathrm{M}$ SYTOX green for $15 \mathrm{~min}$ at room temperature. Finally, the plates were washed once with PBs and were observed to Zeiss AxioVert 25 microscope with the GFP filter (Carl Zeiss, Oberkochen, Germany).

\subsection{Hyphal Growth on Solid Media}

C. albicans cells from an overnight culture were diluted to $\mathrm{OD}_{600} 0.2$ and spread on plates of solidified Spider medium supplemented with ZNGs. The plates were incubated for five days at $37^{\circ} \mathrm{C}$ and the morphology of the fungal colony was photographed while using a digital camera.

\subsection{Hyphal Growth in Liquid Media}

Fungal cells grown in YPD medium for $18 \mathrm{~h}$ were diluted to obtain a cell concentration of $1 \times 10^{6}$ cells $/ \mathrm{mL}$ in Spider broth containing different concentrations of hybrid nanomaterials. Cells were incubated at $37^{\circ} \mathrm{C}$ with agitation $(250 \mathrm{rpm})$ for $2.5 \mathrm{~h}$ and then fungal cells were visualized by Zeiss AxioVert 25 microscope. The percentages of short and long hyphae were counted manually in relation to the total cells per image. 


\subsection{Cell Culture and Treatments}

The human keratinocyte cell line $\mathrm{HaCaT}$, spontaneously immortalized from a primary culture of keratinocytes [34], was cultured in Dulbecco's Modified Eagle's Medium (DMEM; Euroclone, Pero, MI, Italy), supplemented with $10 \%$ fetal bovine serum and antibiotics and was maintained in a humidified incubator with $5 \% \mathrm{CO}_{2}$ at $37^{\circ} \mathrm{C}$.

The suspensions of ZNGs were freshly prepared in DMEM or DMEM with $4 \%$ glycerol followed by $30 \mathrm{~min}$ bath-sonication, and subsequently diluted.

\subsection{Cell Viability and Proliferation of Human Keratinocytes}

For the vitality assay, $2.5 \times 10^{4} \mathrm{HaCaT}$ cells were seeded on 24-well plates and cultured overnight. Subsequently, cultures were incubated or not with $10,20,40$, and $50 \mu \mathrm{g} / \mathrm{mL}$ of ZNGs in DMEM or DMEM with $4 \%$ glycerol for $24 \mathrm{~h}$ (cell viability) or 10 and $50 \mu \mathrm{g} / \mathrm{mL}$ of ZNGs in DMEM with $4 \%$ glycerol for 24,48 , and $72 \mathrm{~h}$ (cell proliferation). Cells were detached by $0.05 \%$ trypsin-ethylenediaminetetraacetic acid (EDTA) solution and stained with Trypan blue for $2 \mathrm{~min}$. The number of dead and viable cells was obtained by counting manually using a hemocytometer. Cell viability was expressed as total number of living cells. For cell proliferation, the number of cells was compared to that counted before treatment $(\mathrm{t} 0)$. Values are representative of three independent experiments.

\subsection{MTT Assay}

$\mathrm{HaCaT}$ cells were seeded on glass slides coated with ZNGs and cultured for 24 or $48 \mathrm{~h}$. Tetrazolium salts (MTT: 3-(4,5-dimethylthiazol-2-yl)-2,5-diphenyltetrazolium bromide, $5 \mathrm{mg} / \mathrm{mL}$ suspended in PBS), was added to each well and incubated for $4 \mathrm{~h}$. The formazan crystals are extracted from the cells with a solubilizing solution (DMSO). An ELISA reader (Thermo Fisher, Phadia AB, Uppsala, Sweden). was used to measure the optical density at a wavelength of $570 \mathrm{~nm}$ and reference length $630 \mathrm{~nm}$. The results were expressed as optical density values.

\subsection{Intracellular ROS Detection in Human Keratinocytes}

$\mathrm{HaCaT}$ cells, which were grown on glass coverslips, were treated or not for $24 \mathrm{~h}$ with 10 or $50 \mu \mathrm{g} / \mathrm{mL}$ of ZNGs suspended in DMEM with $4 \%$ glycerol, and subsequently incubated with $\mathrm{H}_{2}$ DCFDA, $10 \mu \mathrm{M}$, at $37^{\circ} \mathrm{C}$ for $15 \mathrm{~min}$. The detection of ROS was assessed at microscope by evaluating the number of positive cells for ROS production as compared to the total number of counted cells.

\subsection{Immunofluorescence Microscopy}

For immunofluorescence, $2.5 \times 10^{4} \mathrm{HaCaT}$ cells were seeded onto glass coverslips placed in 24-well plates and allowed to adhere. Subsequently, cells were treated for $24 \mathrm{~h}$ with $10 \mathrm{or} 50 \mu \mathrm{g} / \mathrm{mL}$ of ZNGs in DMEM plus $4 \%$ glycerol. The cells were then fixed with $4 \%$ paraformaldehyde in PBS for 30 minutes, treated with $0.1 \mathrm{M}$ glycine in PBS for $20 \mathrm{~min}$, and with $0.1 \%$ Triton X-100 in PBS for additional $5 \mathrm{~min}$ to allow permeabilization. For the evaluation of the tubulin organization, the cells were incubated with the monoclonal antibody $\alpha$-tubulin conjugated to fluorescein isothiocyanate (anti- $\alpha$-tubulin-FITC) for $45 \mathrm{~min}$. To analyze cytoskeletal actin reorganization, the cells were incubated with rhodamine-conjugated phalloidin (TRITC-phalloidin) for $45 \mathrm{~min}$. The fluorescence signal was analyzed while using an Axio Observer inverted microscope, equipped with the ApoTome System (Carl Zeiss, Oberkochen, Germany).

\subsection{Statistical Analysis}

All data were expressed as mean values with the corresponding standard deviations (SD). To determine the significant differences, ANOVA analysis, followed by Bonferroni's test, was conducted by using GraphPad Prism version 5.0 (San Diego, CA, USA). 


\section{Conclusions}

The urgency of new compounds against $C$. albicans has been increased due to the failure of existing therapies and the development of drug resistance in clinical isolates. Germ tube and biofilm formation are important virulence factors that play an important role in the pathogenicity of this opportunistic fungus.

In this study, we investigated the anticandidal activity of ZNGs. We demonstrated that this nanomaterial not only affects the cell survival of $C$. albicans, but it also alters the pathogenicity of this fungus by shooting its virulence factor, like the elongation of germ tube and biofilm formation. In addition, our data indicate that the toxicity of ZNGs is partially associated to an increase of the ROS level in fungal cells. Furthermore, we tested the biocompatibility of this hybrid nanomaterial on $\mathrm{HaCaT}$ cells. We found that the exposure to ZNGs did not impair the proliferation and viability of keratinocyte cells, especially when ZNGs aggregation was reduced by adding glycerol to nanomaterial suspensions or by growing HaCat cells on glass slides that were coated with ZNGs.

In conclusion, our nanomaterial composed by $\mathrm{ZnO}$ nanorods-decorated graphene nanoplateles has proven itself a promising agent against $C$. albicans infections.

Supplementary Materials: The following are available online at http:/ / www.mdpi.com/2079-4991/8/10/752/ s1, Figure S1: Immunofluorescence analysis of actin cytoskeleton of HaCaT cells by TRITC-phalloidin, after treatment with ZNGs for $24 \mathrm{~h}$. White arrows indicate filopodia. Scale bar represents $20 \mu \mathrm{m}$; Figure S2: Field emission scanning electron microscopy (FE-SEM) images of (a), (b) and (c) ZnO-NRs-decorated GNPs (ZNGs) and (d) pristine GNPs.

Author Contributions: Conceived and designed the experiments: P.M., D.U., M.S.S. Wrote the paper: G.F., D.U., P.M. Critical revision of the manuscript: P.M., D.U., M.S.S. Performed the material fabrication and characterization: D.C. Experiments on C.albicans: G.F. Did biocompatibility tests: G.T., M.G.D.C. Analyzed and supervised data: D.U., P.M., M.S.S. All authors read and approved the final manuscript.

Funding: This research received no external funding.

Acknowledgments: The authors are very thankful to Francesco Mura for kindly providing pristine-GNP SEM images.

Conflicts of Interest: The authors declare no conflict of interest.

\section{References}

1. Flores-Mireles, A.L.; Walker, J.N.; Caparon, M.; Hultgren, S.J. Urinary tract infections: Epidemiology, mechanisms of infection and treatment options. Nat. Rev. Microbiol. 2015, 13, 269-284. [CrossRef] [PubMed]

2. Kett, D.H.; Azoulay, E.; Echeverria, P.M.; Vincent, J.L.; Extended Prevalence of Infection in ICU Study (EPIC II) Group of Investigators. Candida bloodstream infections in intensive care units: Analysis of the extended prevalence of infection in intensive care unit study. Crit. Care Med. 2011, 39, 665-670. [CrossRef] [PubMed]

3. Gudlaugsson, O.; Gillespie, S.; Lee, K.; Vande Berg, J.; Hu, J.; Messer, S.; Herwaldt, L.; Pfaller, M.; Diekema, D. Attributable mortality of nosocomial candidemia, revisited. Clin. Infect. Dis. 2003, 37, 1172-1177. [CrossRef] [PubMed]

4. Mayer, F.L.; Wilson, D.; Hube, B. Candida albicans pathogenicity mechanisms. Virulence 2013, 4, 119-128. [CrossRef] [PubMed]

5. Calderone, R.A.; Fonzi, W.A. Virulence factors of Candida albicans. Trends Microbiol. 2001, 9, $327-335$. [CrossRef]

6. Cowen, L.E.; Steinbach, W.J. Stress, drugs, and evolution: The role of cellular signaling in fungal drug resistance. Eukaryot. Cell 2008, 7, 747-764. [CrossRef] [PubMed]

7. Siddiqi, K.S.; Ur Rahman, A.; Tajuddin; Husen, A. Properties of zinc oxide nanoparticles and their activity against microbes. Nanoscale Res. Lett. 2018, 13. [CrossRef] [PubMed]

8. Sahoo, S. Socio-ethical issues and nanotechnology development: Perspectives from India. In Proceedings of the 2010 10th IEEE Conference on Nanotechnology (IEEE-NANO), Seoul, Korea, 17-20 August 2010; pp. 1205-1210.

9. Zhang, Y.; Park, S.J. Incorporation of $\mathrm{RuO}_{2}$ into charcoal-derived carbon with controllable microporosity by $\mathrm{CO}_{2}$ activation for high-performance supercapacitor. Carbon 2017, 122, 287-297. [CrossRef] 
10. Zhang, Y.; Park, S.J. Bimetallic AuPd alloy nanoparticles deposited on $\mathrm{MoO}_{3}$ nanowires for enhanced visible-light driven trichloroethylene degradation. J. Catal. 2018, 361, 238-247. [CrossRef]

11. Wang, M.D.; Shin, D.M.; Simons, J.W.; Nie, S. Nanotechnology for targeted cancer therapy. Expert Rev. Anticancer Ther. 2007, 7, 833-837. [CrossRef] [PubMed]

12. Alivisatos, P. The use of nanocrystals in biological detection. Nat. Biotechnol. 2004, 22, 47-52. [CrossRef] [PubMed]

13. Daniel, M.C.; Astruc, D. Gold nanoparticles: Assembly, supramolecular chemistry, quantum-size-related properties, and applications toward biology, catalysis, and nanotechnology. Chem. Rev. 2004, 104, 293-346. [CrossRef] [PubMed]

14. Rai, M.; Yadav, A.; Gade, A. Silver nanoparticles as a new generation of antimicrobials. Biotechnol. Adv. 2009, 27, 76-83. [CrossRef] [PubMed]

15. Sawai, J. Quantitative evaluation of antibacterial activities of metallic oxide powders $(\mathrm{ZnO}, \mathrm{MgO}$ and $\mathrm{CaO})$ by conductimetric assay. J. Microbiol. Methods 2003, 54, 177-182. [CrossRef]

16. Jones, N.; Ray, B.; Ranjit, K.T.; Manna, A.C. Antibacterial activity of ZnO nanoparticle suspensions on a broad spectrum of microorganisms. FEMS Microbiol. Lett. 2008, 279, 71-76. [CrossRef] [PubMed]

17. Emami-Karvani, Z.; Pegah, C. Antibacterial Activity of Zno Nanoparticle on Gram-Positive and Gram-Negative Bacteria. Afr. J. Microbiol. Res. 2012, 5, 1368-1373. [CrossRef]

18. Raghupathi, K.R.; Koodali, R.T.; Manna, A.C. Size-dependent bacterial growth inhibition and mechanism of antibacterial activity of zinc oxide nanoparticles. Langmuir 2011, 27, 4020-4028. [CrossRef] [PubMed]

19. Hackenberg, S.; Scherzed, A.; Technau, A.; Froelich, K.; Hagen, R.; Kleinsasser, N. Functional responses of human adipose tissue-derived mesenchymal stem cells to metal oxide nanoparticles in vitro. J. Biomed. Nanotechnol. 2013, 9, 86-95. [CrossRef] [PubMed]

20. Kumar, R.; Umar, A.; Kumar, G.; Nalwa, H.S. Antimicrobial properties of ZnO nanomaterials: A review. Ceram. Int. 2017, 43, 3940-3961. [CrossRef]

21. Wang, T.X.; Lou, T.J. Solvothermal synthesis and photoluminescence properties of $\mathrm{ZnO}$ nanorods and nanorod assemblies from $\mathrm{ZnO}_{2}$ nanoparticles. Mater. Lett. 2008, 62, 2329-2331. [CrossRef]

22. Jang, J.S.; Yu, C.J.; Choi, S.H.; Ji, S.M.; Kim, E.S.; Lee, J.S. Topotactic synthesis of mesoporous ZnS and ZnO nanoplates and their photocatalytic activity. J. Catal. 2008, 254, 144-155. [CrossRef]

23. Ding, Y.; Wang, Z.L. Structures of planar defects in ZnO nanobelts and nanowires. Micron 2009, 40, 335-342. [CrossRef] [PubMed]

24. Wang, H.; Wang, J.; Deng, X.; Sun, H.; Shi, Z.; Gu, Z.; Liu, Y.; Zhao, Y. Biodistribution of carbon single-wall carbon nanotubes in mice. J. Nanosci. Nanotechnol. 2004, 4, 1019-1024. [CrossRef] [PubMed]

25. Kakiuchi, K.; Hosono, E.; Kimura, T.; Imai, H.; Fujihara, S. Fabrication of mesoporous ZnO nanosheets from precursor templates grown in aqueous solutions. J. Sol-Gel Sci. Technol. 2006, 39, 63-72. [CrossRef]

26. Wang, Z.L. Nanostructures of zinc oxide. Mater. Today 2004, 7, 26-33. [CrossRef]

27. Mahmud, S.; Johar Abdullah, M.; Putrus, G.A.; Chong, J.; Karim Mohamad, A. Nanostructure of ZnO fabricated via french process and its correlation to electrical properties of semiconducting varistors. Synth. React. Inorg. Met. 2006, 36, 155-159. [CrossRef]

28. He, L.; Liu, Y.; Mustapha, A.; Lin, M. Antifungal activity of zinc oxide nanoparticles against Botrytis cinerea and Penicillium expansum. Microbiol. Res. 2011, 166, 207-215. [CrossRef] [PubMed]

29. Eskandari, M.; Haghighi, N.; Ahmadi, V.; Haghighi, F.; Mohammadi, S.R. Growth and investigation of antifungal properties of $\mathrm{ZnO}$ nanorod arrays on the glass. Phys. B Condens. Matter 2011, 406, 112-114. [CrossRef]

30. Oberdorster, G.; Maynard, A.; Donaldson, K.; Castranova, V.; Fitzpatrick, J.; Ausman, K.; Carter, J.; Karn, B.; Kreyling, W.; Lai, D.; et al. Principles for characterizing the potential human health effects from exposure to nanomaterials: Elements of a screening strategy. Part. Fibre Toxicol. 2005, 2. [CrossRef] [PubMed]

31. Fischer, H.C.; Chan, W.C. Nanotoxicity: The growing need for in vivo study. Curr. Opin. Biotechnol. 2007, 18, 565-571. [CrossRef] [PubMed]

32. Jeevanandam, J.; San Chan, Y.; Danquah, M.K. Nano-formulations of drugs: Recent developments, impact and challenges. Biochimie 2016, 128-129, 99-112. [CrossRef] [PubMed]

33. Ryman-Rasmussen, J.P.; Riviere, J.E.; Monteiro-Riviere, N.A. Penetration of intact skin by quantum dots with diverse physicochemical properties. Toxicol. Sci. 2006, 91, 159-165. [CrossRef] [PubMed] 
34. Boukamp, P.; Petrussevska, R.T.; Breitkreutz, D.; Hornung, J.; Markham, A.; Fusenig, N.E. Normal keratinization in a spontaneously immortalized aneuploid human keratinocyte cell line. J. Cell Biol. 1988, 106, 761-771. [CrossRef] [PubMed]

35. Hu, X.; Zhang, Y.; Zhao, X.; Hwang, H.M. Biodegradation of benzo[ $\alpha]$ pyrene with immobilized laccase: Genotoxicity of the products in HaCat and A3 cells. Environ. Mol. Mutagen. 2007, 48, 106-113. [CrossRef] [PubMed]

36. Jirova, D.; Kejlova, K.; Bendova, H.; Ditrichova, D.; Mezulanikova, M. Phototoxicity of bituminous tars-correspondence between results of 3T3 NRU PT, 3D skin model and experimental human data. Toxicol. In Vitro 2005, 19, 931-934. [CrossRef] [PubMed]

37. Lelievre, D.; Justine, P.; Christiaens, F.; Bonaventure, N.; Coutet, J.; Marrot, L.; Cotovio, J. The EpiSkin phototoxicity assay (EPA): Development of an in vitro tiered strategy using 17 reference chemicals to predict phototoxic potency. Toxicol. In Vitro 2007, 21, 977-995. [CrossRef] [PubMed]

38. Zanni, E.; De Palma, S.; Chandraiahgari, C.R.; De Bellis, G.; Cialfi, S.; Talora, C.; Palleschi, C.; Sarto, M.S.; Uccelletti, D.; Mancini, P. In vitro toxicity studies of zinc oxide nano- and microrods on mammalian cells: A comparative analysis. Mater. Lett. 2016, 179, 90-94. [CrossRef]

39. Padmavathy, N.; Vijayaraghavan, R. Enhanced bioactivity of ZnO nanoparticles-an antimicrobial study. Sci. Technol. Adv. Mater. 2008, 9, 035004. [CrossRef] [PubMed]

40. Colon, G.; Ward, B.C.; Webster, T.J. Increased osteoblast and decreased Staphylococcus epidermidis functions on nanophase $\mathrm{ZnO}$ and $\mathrm{TiO}_{2}$. J. Biomed. Mater. Res. A 2006, 78, 595-604. [CrossRef] [PubMed]

41. Zanni, E.; Bruni, E.; Chandraiahgari, C.R.; De Bellis, G.; Santangelo, M.G.; Leone, M.; Bregnocchi, A.; Mancini, P.; Sarto, M.S.; Uccelletti, D. Evaluation of the antibacterial power and biocompatibility of zinc oxide nanorods decorated graphene nanoplatelets: New perspectives for antibiodeteriorative approaches. J. Nanobiotechnol. 2017, 15. [CrossRef] [PubMed]

42. Zanni, E.; Chandraiahgari, C.R.; De Bellis, G.; Montereali, M.R.; Armiento, G.; Ballirano, P.; Polimeni, A.; Sarto, M.S.; Uccelletti, D. Zinc oxide nanorods-decorated graphene nanoplatelets: A promising antimicrobial agent against the cariogenic bacterium Streptococcus mutans. Nanomaterials 2016, 6, 179. [CrossRef] [PubMed]

43. Lipovsky, A.; Nitzan, Y.; Gedanken, A.; Lubart, R. Antifungal activity of ZnO nanoparticles-The role of ROS mediated cell injury. Nanotechnology 2011, 22, 105101. [CrossRef] [PubMed]

44. Liang, Y.; Wei, D.; Wang, H.; Xu, N.; Zhang, B.; Xing, L.; Li, M. Role of Candida albicans Aft2p transcription factor in ferric reductase activity, morphogenesis and virulence. Microbiology 2010, 156, 2912-2919. [CrossRef] [PubMed]

45. Jin, M.; Yaung, J.; Kannan, R.; He, S.; Ryan, S.J.; Hinton, D.R. Hepatocyte growth factor protects RPE cells from apoptosis induced by glutathione depletion. Investig. Ophthalmol. Vis. Sci. 2005, 46, 4311-4319. [CrossRef] [PubMed]

46. Sirelkhatim, A.; Mahmud, S.; Seeni, A.; Kaus, N.H.M.; Ann, L.C.; Bakhori, S.K.M.; Hasan, H.; Mohamad, D. Review on Zinc Oxide Nanoparticles: Antibacterial Activity and Toxicity Mechanism. Nano-Micro Lett. 2015, 7, 219-242. [CrossRef]

47. Gow, N.A.; Brown, A.J.; Odds, F.C. Fungal morphogenesis and host invasion. Curr. Opin. Microbiol. 2002, 5, 366-371. [CrossRef]

48. Heilmann, C.J.; Sorgo, A.G.; Siliakus, A.R.; Dekker, H.L.; Brul, S.; de Koster, C.G.; de Koning, L.J.; Klis, F.M. Hyphal induction in the human fungal pathogen Candida albicans reveals a characteristic wall protein profile. Microbiology 2011, 157, 2297-2307. [CrossRef] [PubMed]

49. Trochin, G.; Bouchara, J.P.; Robert, R.; Senet, J.M. Adherence of Candida albicans germ tubes to plastic: Ultrastructural and molecular studies of fibrillar adhesions. Infect. Immun. 1988, 56, 1987-1993.

50. Zamperini, C.A.; André, R.S.; Longo, V.M.; Mima, E.G.; Vergani, C.E.; Machado, A.L.; Varela, J.A.; Longo, E. Antifungal applications of Ag-decorated hydroxyapatite nanoparticles. J. Nanomater. 2013. [CrossRef]

51. Halbandge, S.D.; Mortale, S.P.; Karuppayil, S.M. Biofabricated silver nanoparticles synergistically activate amphotericin B against mature biofilm forms of Candida albicans. Open Nanomed. J. 2017, 4. [CrossRef]

52. Dananjaya, S.H.S.; Udayangani, R.M.C.; Oh, C.; Nikapitiya, C.; Lee, J.; De Zoysa, M. Green synthesis, physio-chemical characterization and anti-candidal function of biocompatible chitosan gold nanocomposite as a promising antifungal therapeutic agent. RSC Adv. 2017, 7. [CrossRef] 
53. Jalal, M.; Ansari, M.A.; Ali, S.G.; Khan, H.M.; Rehman, S. Anticandidal activity of bioinspired ZnO NPs: Effect on growth, cell morphology and key virulence attributes of Candida species. Artif. Cells Nanomed. Biotechnol. 2018. [CrossRef] [PubMed]

54. Donlan, R.M. Biofilms and device-associated infections. Emerg. Infect. Dis. 2001, 7, 277-281. [CrossRef] [PubMed]

55. Chandra, J.; Mukherjee, P.K.; Ghannoum, M.A. Candida biofilms associated with CVC and medical devices. Mycoses 2011, 55, 46-57. [CrossRef]

56. Taff, H.T.; Mitchell, K.F.; Edward, J.A.; Andes, D.R. Mechanisms of Candida biofilm drug resistance. Future Microbiol. 2013, 8, 1325-1337. [CrossRef] [PubMed]

57. Maubon, D.; Garnaud, C.; Calandra, T.; Sanglard, D.; Cornet, M. Resistance of Candida spp. to antifungal drugs in the ICU: Where are we now? Intensive Care Med. 2014, 40, 1241-1255. [CrossRef] [PubMed]

58. Darouiche, R.O.; Mansouri, M.D.; Kojic, E.M. Antifungal activity of antimicrobial-impregnated devices. Clin. Microbiol. Infect. 2006, 12, 397-399. [CrossRef] [PubMed]

59. White, T.C.; Marr, K.A.; Bowden, R.A. Clinical, cellular, and molecular factors that contribute to antifungal drug resistance. Clin. Microbiol. Rev. 1998, 11, 382-402. [PubMed]

60. Yu, Q.; Li, J.; Zhang, Y.; Wang, Y.; Liu, L.; Li, M. Inhibition of gold nanoparticles (AuNPs) on pathogenic biofilm formation and invasion to host cells. Sci. Rep. 2016, 6, 26667. [CrossRef] [PubMed]

61. Cremonini, E.; Zonaro, E.; Donini, M.; Lampis, S.; Boaretti, M.; Dusi, S.; Melotti, P.; Lleo, M.M.; Vallini, G. Biogenic selenium nanoparticles: Characterization, antimicrobial activity and effects on human dendritic cells and fibroblasts. Microb. Biotechnol. 2016, 9, 758-771. [CrossRef] [PubMed]

62. Divya, M.; Vaseeharan, B.; Abinaya, M.; Vijayakumar, S.; Govindarajan, M.; Alharbi, N.S.; Kadaikunnan, S.; Khaled, J.M.; Benelli, G. Biopolymer gelatin-coated zinc oxide nanoparticles showed high antibacterial, antibiofilm and anti-angiogenic activity. J. Photochem. Photobiol. B 2018, 178, 211-218. [CrossRef] [PubMed]

63. Barad, S.; Roudbary, M.; Omran, A.N.; Daryasari, M.P. Preparation and characterization of ZnO nanoparticles coated by chitosan-linoleic acid; fungal growth and biofilm assay. Bratisl. Lek Listy 2017, 118, 169-174. [CrossRef] [PubMed]

64. Harper, B.; Sinche, F.; Ho Wu, R.; Gowrishankar, M.; Marquart, G.; Mackiewicz, M.; Harper, S.L. The Impact of surface ligands and synthesis method on the toxicity of Glutathione-coated gold nanoparticles. Nanomaterials 2014, 4, 355-371. [CrossRef] [PubMed]

65. Liao, K.H.; Lin, Y.S.; Macosko, C.W.; Haynes, C.L. Cytotoxicity of graphene oxide and graphene in human erythrocytes and skin fibroblasts. ACS Appl. Mater. Interfaces 2011, 3, 2607-2615. [CrossRef] [PubMed]

66. Mahanta, S.; Paul, S. Bovine alpha-lactalbumin functionalized graphene oxide nano-sheet exhibits enhanced biocompatibility: A rational strategy for graphene-based targeted cancer therapy. Colloids Surf. B Biointerfaces 2015, 134, 178-187. [CrossRef] [PubMed]

67. Kim, J.; Jay, M. Neutron-activatable radionuclide cancer therapy using graphene oxide nanoplatelets. Nucl. Med. Biol. 2017, 52, 42-48. [CrossRef] [PubMed]

68. Rousseau, D. Fat crystals and emulsion stability-a review. Food Res. Int. 2000, 33, 3-14. [CrossRef]

69. Staszek, M.; Siegel, J.; Rimpelová, S.; Lyutakov, O.; Švorčík, V. Cytotoxicity of noble metal nanoparticles sputtered into glycerol. Mater. Lett. 2015, 158, 351-354. [CrossRef]

70. Corrales, R.M.; Luo, L.; Chang, E.Y.; Pflugfelder, S.C. Effects of Osmoprotectants on Hyperosmolar Stress in Cultured Human Corneal Epithelial Cells. Cornea 2008, 27, 574-579. [CrossRef] [PubMed]

71. Brouhard, G.J.; Rice, L.M. Microtubule dynamics: An interplay of biochemistry and mechanics. Nat. Rev. Mol. Cell Biol. 2018, 19, 451-463. [CrossRef] [PubMed]

72. Heckman, C.A.; Plummer, H.K. Filopodia as sensors. Cell. Signal. 2013, 25, 2298-2311. [CrossRef] [PubMed]

73. Chandraiahgari, C.R.; De Bellis, G.; Ballirano, P.; Balijepalli, S.K.; Kaciulis, S.; Caneve, L.; Sarto, F.; Sarto, M.S. Synthesis and characterization of $\mathrm{ZnO}$ nanorods with a narrow size distribution. RSC Adv. 2015, 5, 49861-49870. [CrossRef]

74. Xia, T.; Kovochich, M.; Liong, M.; Mädler, L.; Gilbert, B.; Shi, H.; Yeh, J.I.; Zink, J.I.; Nel, A.E. Comparison of the mechanism of toxicity of zinc oxide and cerium oxide nanoparticles based on dissolution and oxidative stress properties. ACS Nano 2008, 2, 2121-2134. [CrossRef] [PubMed]

75. Xia, T.; Zhao, Y.; Sager, T.; George, S.; Pokhrel, S.; Li, N.; Schoenfeld, D.; Meng, H.; Lin, S.; Wang, X.; et al. Decreased dissolution of $\mathrm{ZnO}$ by iron doping yields nanoparticles with reduced toxicity in the rodent lung and zebrafish embryos. ACS Nano 2011, 5, 1223-1235. [CrossRef] [PubMed] 
76. Liu, X.; Rodeheaver, D.P.; White, J.C.; Wright, A.M.; Walker, L.M.; Zhang, F.; Shannon, S. A comparison of in vitro cytotoxicity assays in medical device regulatory studies. Regul. Toxicol. Pharmacol. 2018, 97, 24-32. [CrossRef] [PubMed]

77. Lasocka, I.; Szulc-Dabrowska, L.; Skibniewski, M.; Skibniewska, E.; Strupinski, W.; Pasternak, I.; Kmieć, H.; Kowalczyk, P. Biocompatibility of pristine graphene monolayer: Scaffold for fibroblasts. Toxicol. In Vitro 2018, 48, 276-285. [CrossRef] [PubMed]

78. Wang, Y.W.; Cao, A.; Jiang, Y.; Zhang, X.; Liu, J.H.; Liu, Y.; Wang, H. Superior antibacterial activity of zinc oxide/graphene oxide composites originating from high zinc concentration localized around bacteria. ACS Appl. Mater. Interfaces 2014, 6, 2791-2798. [CrossRef] [PubMed]

79. Solis More, Y.; Panella, G.; Fioravanti, G.; Perrozzi, F.; Passacantando, M.; Giansanti, F.; Ardini, M.; Ottaviano, L.; Cimini, A.; Peniche, C.; et al. Biocompatibility of composites based on chitosan, apatite, and graphene oxide for tissue applications. J. Biomed. Mater. Res. A 2018, 106, 1585-1594. [CrossRef] [PubMed]

80. Wang, Y.; Zhou, Y.; Wang, X.; Liu, Y.; Wen, S.; Zheng, X.; Wang, P. Cytocompatibility and in vivo biodegradation of graphene-modified chitosan 3D porous scaffold. Mater. Lett. 2018, 220. [CrossRef]

81. Chandraiahgari, C.R.; De Bellis, G.; Balijepalli, S.K.; Kaciulis, S.; Ballirano, P.; Migliori, A.; Morandi, V.; Caneve, L.; Sarto, F.; Sarto, M.S. Control of the size and density of ZnO-nanorods grown onto graphene nanoplatelets in aqueous suspensions. RSC Adv. 2016, 6, 83217-83225. [CrossRef]

82. Liu, H.; Kohler, J.; Fink, G.R. Suppression of hyphal formation in Candida albicans by mutation of a STE12 homolog. Science 1994, 266, 1723-1726. [CrossRef] [PubMed]

83. Thein, Z.M.; Samaranayake, Y.H.; Samaranayake, L.P. In vitro biofilm formation of Candida albicans and non-albicans Candida species under dynamic and anaerobic conditions. Arch. Oral Biol. 2007, 52, 761-767. [CrossRef] [PubMed]

(C) 2018 by the authors. Licensee MDPI, Basel, Switzerland. This article is an open access article distributed under the terms and conditions of the Creative Commons Attribution (CC BY) license (http:/ / creativecommons.org/licenses/by/4.0/). 